\title{
STABILISASI DIMENSI KAYU DENGAN APLIKASI PARAFIN CAIR
}

\author{
Dimensional Stability of Wood with Application of Liquid Paraffine \\ Syahidah dan Tekat Dwi Cahyono
}

\begin{abstract}
Wood is a special material which can swell and shrink with the change of environmental humidity. The aim of this research was to enhance the dimensional stability of wood. Clear specimens of jackfruit wood (Artocarpus heterophyllus) ) measuring $15 \mathrm{~cm}(\mathrm{~L}) \times 2 \mathrm{~cm}(\mathrm{R}) \times 2 \mathrm{~cm}(\mathrm{~T})$ and mangium wood (Acacia mangium Wild.) measuring $5 \mathrm{~cm}(\mathrm{~L}) \times 5 \mathrm{~cm}(\mathrm{R}) \times 5 \mathrm{~cm}(\mathrm{~T})$ were prepared for treatment. The samples were firstly soaked in a liquid paraffin with $0 \%$ concentration (100\% kerosene soluble), $33.3 \%, 66,6 \%$ and $100 \%$. All samples were then vacuumed for 1 hour and soaked in water for 24 hours. Results indicated that the best response for dimensional stability was performed by mangium with $33 \%$ paraffin and jackfruit wood with $66 \%$ paraffine. In addition, moisture content of all treated samples decreased after treatment. This research also showed that the treatment had no significant effect to MOE, MOR and hardness of the wood.
\end{abstract}

Key words: Dimensional stability of wood, liquid parafin, mangium, jackfruit wood

\section{PENDAHULUAN}

Pemanfaatan kayu dalam kehidupan manusia dewasa ini semakin maju seiring dengan kemajuan teknologi di bidang pengolahan kayu. Pemanfaatan kayu sekarang ini bukan hanya dalam bentuk kayu utuh saja tetapi juga dalam berbagai bentuk turunan kayu yang kadang-kadang tidak lagi menampakkan wujud asalnya. Meskipun demikian, pemanfaatan kayu dalam bentuk kayu utuh masih memegang peranan yang sangat penting dan kadang-kadang tidak dapat digantikan dengan bentuk lain. Untuk memaksimalkan pemanfaatan kayu utuh, perlu diketahui beberapa kelemahan kayu agar dapat diminimalisir. Salah satu kelemahan kayu yang sangat merugikan dalam penggunaannya adalah sifat kembang susut yang sangat mempengaruhi stabilisasi dimensi kayu.

Kayu merupakan material yang dimensinya tidak stabil, karena volume kayu dipengaruhi oleh kadar air kayu. Kayu akan menyusut bila air, $\mathrm{H}_{2} \mathrm{O}$, terdesorpsi dari dinding sel dan mengembang lagi bila $\mathrm{H}_{2} \mathrm{O}$ teradsorpsi ke dalam dinding sel kayu. Hal ini disebabkan karena dalam dinding sel terdapat selulosa amorf, hemiselulosa dan lignin, yang dapat mengikat $\mathrm{H}_{2} \mathrm{O}$, sehingga mempengaruhi dimensi kayu (Walker, 1993). Adsorpsi $\mathrm{H}_{2} \mathrm{O}$ oleh selulosa bergantung pada jumlah gugus- $\mathrm{OH}$ bebas atau gugus- $\mathrm{OH}$ di daerah amorf. Semakin banyak gugus- $\mathrm{OH}$ di daerah amorf, maka akan semakin banyak $\mathrm{H}_{2} \mathrm{O}$ teradsorpsi. Adsorpsi $\mathrm{H}_{2} \mathrm{O}$ oleh dinding sel kayu mula-mula membentuk lapisan molekul tunggal. Pembentukan lapisan ini berlangsung sampai kelembaban kayu $5 \%$. Adsorpsi selanjutnya membentuk lapisan ganda dan menyebabkan dinding sel mengembang. Banyaknya $\mathrm{H}_{2} \mathrm{O}$ yang diadsorpsi sehingga memberikan pengembangan maksimum, dan keadaan ini disebut titik jenuh serat (TJS). $\mathrm{H}_{2} \mathrm{O}$ setelahnya disebut $\mathrm{H}_{2} \mathrm{O}$ bebas, menempati pori atau rongga sel kayu, tidak berikatan dengan selulosa serta tidak mengembangkan kayu (Fengel and Wegener, 1993). Oleh sebab itu, agar dimensi kayu tidak berubah sewaktu digunakan, misalnya sebagai komponen meubel, maka sebelum dijadikan komponen, kayu tersebut harus dikeringkan ke kadar air keseimbangan (KAK) dimana kayu tersebut akan digunakan. Untuk Indonesia KAK berkisar antara 10-17\%, tergantung jenis kayu dan kelembaban nisbi (Relative Humidity=RH) rata-rata dari ruangan (Coto, 2005).

Untuk mengatasi kekurangan kayu tersebut telah dilakukan beberapa modifikasi. Tujuan modifikasi adalah untuk memperbaiki sifat fisis dan mekanis kayu utuh dengan cara mengimpregnasi kayu dengan bahan kimia. Bahan kimia tersebut harus mampu mengembangkan kayu untuk menimbulkan penetrasi dan bereaksi dengan gugus hidroksil pada polimer dinding sel di bawah kondisi asam atau agak basa pada suhu $<120^{\circ} \mathrm{C}$. 
Modifikasi kimia dapat memperbaiki stabilitas dimensi, kekerasan, ketahanan abrasif, keawetan dan ketahanan terhadap api. Salah satu cara modifikasi kimia adalah dengan furfurilasi. Tujuan furfurilasi adalah untuk menyempurnakan sifat kayu inferior terutama kayu dari hutan tanaman, sehingga dapat memenuhi persyaratan teknis yang dibutuhkan. Dari beberapa studi yang telah dilakukan sebelumnya diketahui bahwa furfurilasi dapat meningkatkan berbagai sifat keteguhan kayu dan ketahanan kayu terhadap serangan jamur dan serangga. Dengan furfulisasi melalui perendaman kayu mangium dalam larutan alkohol $98 \%$ dan katalis $5 \% \mathrm{ZnCl}_{2}$ di mana komposisi campuran 95 : 5 dengan pelarut air, kayu mangium kering udara (kadar air 15-18\%), dapat ditingkatkan sifat stabilitas dimensi dan keteguhan mekanisnya hingga 75\% (Malik dkk., 2005). Selain itu, terdapat juga beberapa modifikasi yang telah dilakukan antara lain dengan melakukan asetilasi terhadap kayu. Asetilasi terbukti telah mampu meningkatkan stabilitas dimensi kayu (Ramsden and Blake, 1997). Upaya lain yang dilakukan untuk menjaga stabilisasi dimensi adalah dengan perlakuan perendaman kayu dalam larutan parafin. Hal ini didasari oleh pemikiran bahwa parafin dapat menjadi semacam "bulking agent" dalam kayu yang dapat mengurangi daya serap air sehingga stabilisasi dimensi kayu juga akan terjaga. Diduga parafin ini akan menghalangi penyerapan air dengan menggantikan ion- $\mathrm{OH}$ pada molekul $\mathrm{H}_{2} \mathrm{O}$ sehingga molekul tersebut jenuh dan berakibat tidak akan terjadi penyerapan air. Rendahnya penyerapan cairan oleh kayu antara lain disebabkan oleh struktur anatomi kayu dan adanya udara yang mengisi rongga sel. Oleh karena itu, proses pemasukan parafin ke dalam kayu dilakukan dengan proses pemvakuman dan rendaman dingin (Coto dan Rahayu, 2005).

Penelitian ini dilakukan untuk mengetahui pengaruh pemberian parafin terhadap sifat fisis kayu, sifat mekanis kayu dan perubahan penampakan kayu (perubahan warna kayu).

\section{BAHAN DAN METODE}

Jenis kayu yang digunakan dalam penelitian ini adalah kayu nangka dan kayu mangium berupa sampel kecil bebas cacat berukuran $5 \times 5 \times 5 \mathrm{~cm}$ dan $2 \times 2 \times 15 \mathrm{~cm}$. Konsentrasi parafin yang digunakan dalam penelitian ini adalah $0 \%(100 \%$ pelarut/minyak tanah), 33,3\%, 66.6\%, dan $100 \%$ parafin. Respon yang akan diamati adalah sifat fisis (pengembangan dan penyusutan), jumlah parafin yang masuk ke dalam kayu (WPG) dan sifat mekanis (MOE, MOR dan kekerasan).

Seluruh contoh uji sifat fisis dan mekanis ditimbang berat dan diukur dimensi awal sampel. Kemudian dimasukkan dalam larutan parafin dengan konsentrasi yang telah ditentukan dan divakum selama 1 jam. Setelah vakum dilepaskan, dilanjutkan perendaman selama 24 jam. Sampel yang telah diberi perlakukan ditiriskan, dan diukur berat, dan dimensi setelah perendaman. Selanjutnya dioven dalam suhu $50^{\circ} \mathrm{C}$ selama 24 jam. Setelah dikeluarkan dari oven, contoh uji diukur berat dan dimensinya. Tahap terakhir perlakukan adalah pengkondisian contoh uji selama 2 minggu dan setelah itu diukur berat dan dimensi selepas pengkondisian.

Contoh uji sifat mekanis yang berukuran $2 \times 2$ $x 15 \mathrm{~cm}$ dihitung keteguhan lentur dan kekakuan dengan alat uji sifat fisis mekanis instron. Hasilnya adalah regresi antara beban dan defleksi. Hasil regresi tersebut kemudian dianalisis dan dihitung nilai MOE dan MOR dari contoh uji. Pengujian selanjutnya adalah pengujian kekerasan dengan menggunakan alat uji sifat fisis mekanis amshler. Contoh uji diberi beban yang ujungnya merupakan bola baja berukuran $1 \mathrm{~cm}$ sampai seluruh bola baja masuk ke dalam kayu. Kekerasan kayu diperoleh dari beban yang diberikan dibagi dengan diameter bola baja yang digunakan dalam pengujian.

Pengolahan data menggunakan rancangan faktorial dengan dua faktor, yaitu konsentrasi parafin dan jenis kayu, dengan 3 kali ulangan. Untuk menguji pengaruh tiap perlakuan, digunakan uji beda rataan.

\section{HASIL DAN PEMBAHASAN}

\section{Kadar Air}

Kayu merupakan bahan higroskopis yang sangat mudah menyerap dan mengeluarkan air. Kondisi ini dapat diatasi dengan menambahkan bahan yang dapat mengurangi sifat higroskopis kayu, antara lain parafin cair yang diharapkan dapat menjadi "bulking agent" atau penghalang fisik yang akan menghalangi kontak antara kayu dengan air. Hasil pengukuran kadar air kayu selama proses perlakukan dengan parafin cair disajikan pada Gambar 1. 


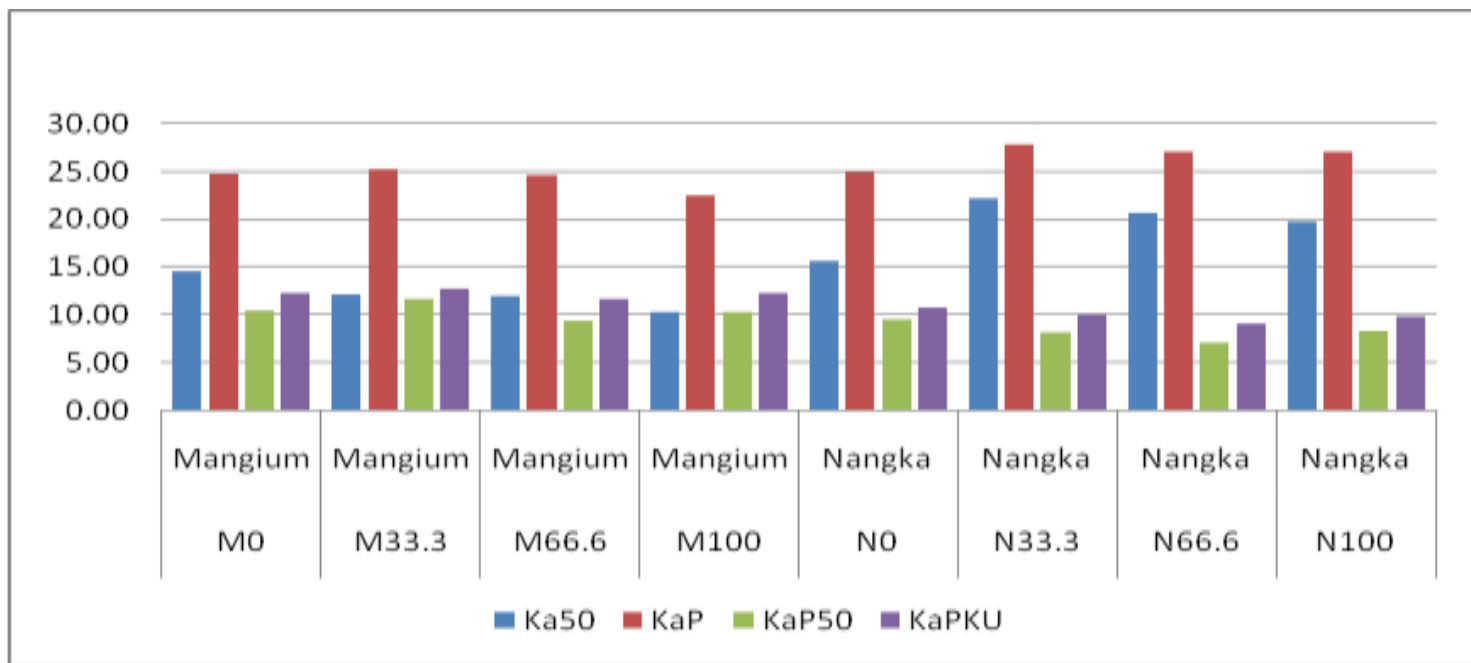

Keterangan : Ka50 = Kadar air setelah dioven $50^{\circ} \mathrm{C}, \mathrm{KaP}=$ Kadar air basah setelah diberi parafin, KaP50 = Kadar air setelah diberi parafin dan dioven $50^{\circ} \mathrm{C}, \mathrm{KaPKU}=$ Kadar air kayu setelah diberi parafin dan dikondisikan selama 1 minggu.

Figure 1. Changes of the Sample Moisture Content during Treatments

Dari data di atas terlihat bahwa kadar air kering udara setelah diberi parafin lebih kecil dibandingkan kadar air kering udara sebelum diberi parafin. Hal ini diduga disebabkan oleh karena parafin memberikan lapisan tipis di permukaan kayu yang berfungsi sebagai penghalang fisik terjadinya kontak antara kayu dengan air sehingga sifat higroskopisitas kayu berkurang.

\section{Pengembangan dan Penyusutan Dimensi.}

Pengamatan perubahan dimensi contoh uji kayu mangium dan nangka selama penelitian dilakukan tiga tahap, yaitu persentase pengembangan contoh uji dari kering oven $50^{\circ} \mathrm{C}$ ke kondisi setelah diberi parafin, persentase penyusutan contoh uji dari pemberian parafin ke kering oven $50{ }^{\circ} \mathrm{C}$ dan yang terakhir pengembangan dari kering oven $50^{\circ} \mathrm{C}$ ke kondisi kering udara. Semua pengamatan pengembangan dan penyusutan dilakukan pada dimensi panjang, tebal dan lebar. Hasil perhitungan pengembangan dan penyusutan dimensi disajikan pada Gambar 2, 3 dan 4

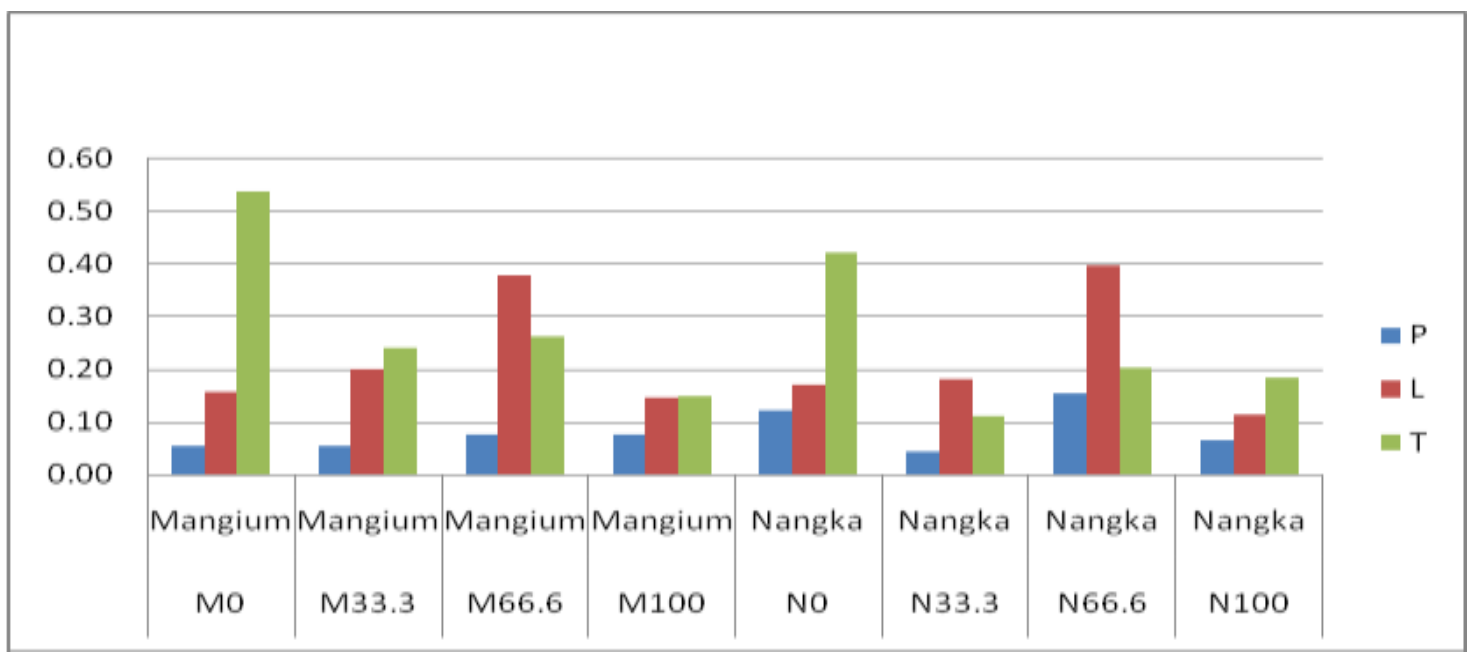

Figure 2. Changes of the Sample Swelling from Oven Dry 50 and After Treatment 


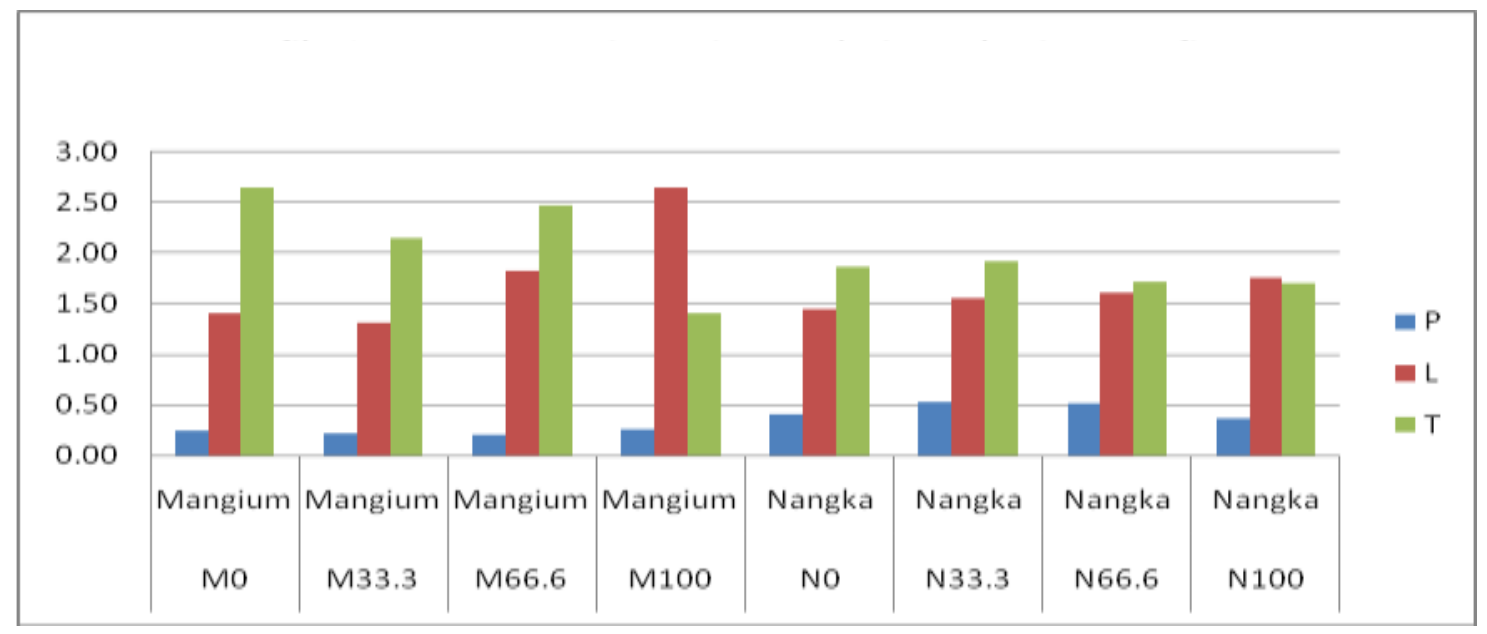

Figure 3. Changes of the Sample Shrinkage After Treatment to Oven Dry 50

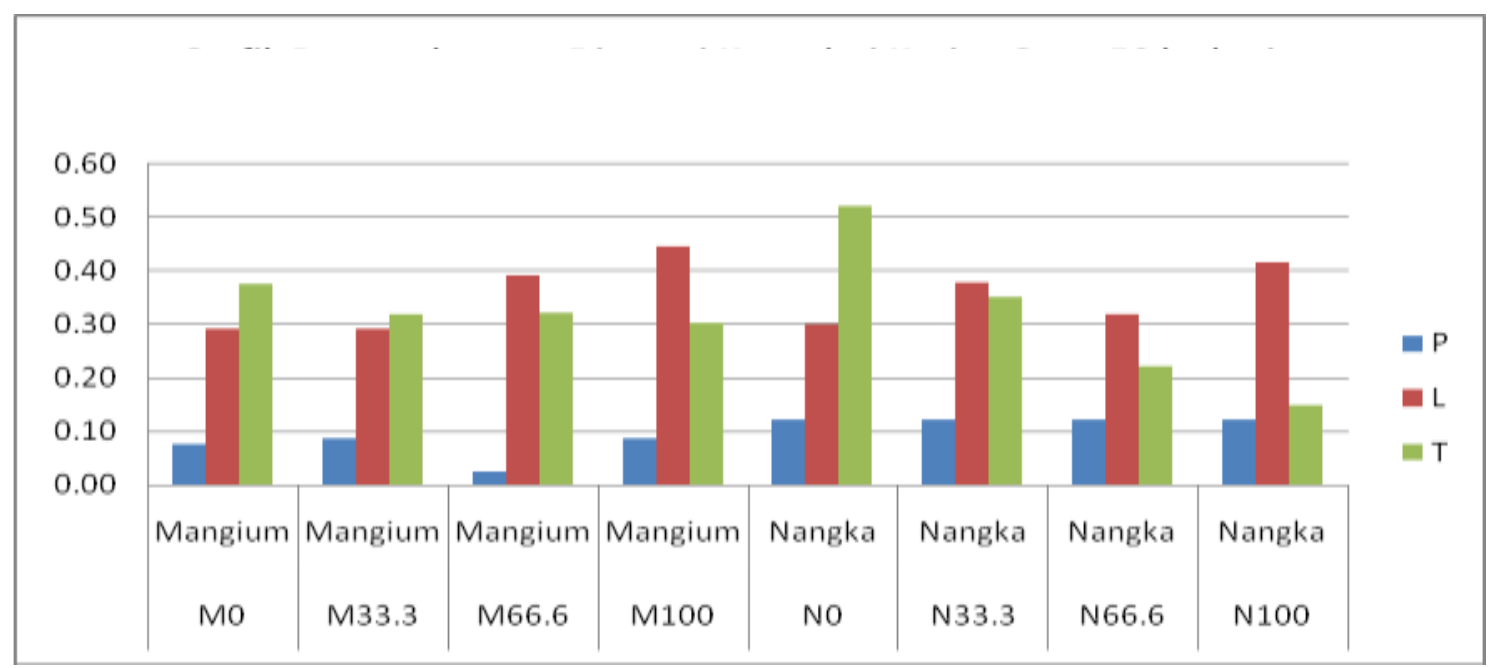

Figure 4. Changes of the Sample Swelling from Oven Dry 50 to Air Dry

Untuk mengetahui respon terbaik dari seluruh perlakuan, dilakukan uji rataan terhadap hasil pengembangan dimensi kayu dari kering oven ke kering udara. Dari hasil uji rataan ditemukan bahwa respon terbaik perlakuan adalah pada pemberian parafin $33 \%$ pada kayu mangium dan pemberian parafin $66 \%$ pada kayu nangka. Adanya perbedaan respon tersebut diduga disebabkan oleh karena adanya perbedaan sifat anatomis, sifat fisik maupun sifat kimia di antara kedua jenis kayu yang dijadikan sampel dalam penelitian ini.

\section{Keteguhan Lentur (MOE), Keteguhan Patah dan Kekerasan.}

Untuk mengetahui pengaruh perlakuan pemberian parafin cair terhadap sifat mekanis kayu yang antara lain digambarkan oleh keteguhan lentur (MOE), keteguhan patah (MOR) dan kekerasan kayu, maka dilakukan pengujian terhadap sampel yang telah diberi perlakuan. Hasil pengujian keteguhan lentur (MOE), keteguhan patah (MOR) dan kekerasan kayu dapat dilihat pada Tabel 1.

Pada Tabel 1 terlihat bahwa nilai MOE tertinggi dicapai oleh kayu mangium pada konsentasi parafin $0 \%$ dan nilai terendah pada kayu nangka dengan konsentrasi parafin 33,3\%. Demikian pula nilai MOR, hasil tertinggi dicapai oleh kayu mangium pada konsentrasi parafin $0 \%$, dan nilai terendah pada kayu nangka pada konsentrasi $33,3 \%$. Sebaliknya nilai kekerasan, secara umum kayu nangka memiliki kekerasan yang lebih baik dibandingkan dengan kayu mangium. Nilai kekerasan tertinggi dicapai oleh 
kayu nangka dengan konsentrasi parafin 33,3\% dan terendah pada kayu mangium pada konsentrasi $66,6 \%$. Hasil uji statistik pengaruh pemberian parafin menunjukkan bahwa pemberian parafin tidak berpengaruh terhadap perubahan nilai
MOE, MOR dan kekerasan kayu, sehingga dapat dikatakan bahwa kayu yang telah diberi parafin tetap aman untuk digunakan sebagai bahan struktural.

Table 1. The MOE, MOR and Hardness of Sample After Treatment

\begin{tabular}{rlccc}
\hline Perlakuan & Jenis Kayu & MOE $\left(\mathrm{kg} / \mathrm{cm}^{2}\right)$ & $\mathrm{MOR}\left(\mathrm{kg} / \mathrm{cm}^{2}\right)$ & Kekerasan $\left(\mathrm{kg} / \mathrm{cm}^{2}\right)$ \\
\hline $0 \%$ & Mangium & $61.748,05$ & 979,76 & 409,34 \\
$33,3 \%$ & Mangium & $58.087,48$ & 947,42 & 403,67 \\
$66,6 \%$ & Mangium & $54.445,20$ & 925,24 & 366,01 \\
$100 \%$ & Mangium & $58.549,32$ & 904,53 & 376,01 \\
$0 \%$ & Nangka & $21.980,90$ & 383,94 & 529,34 \\
$33,3 \%$ & Nangka & $21.974,83$ & 300.98 & 567,67 \\
$66,6 \%$ & Nangka & $36.498,39$ & 476,10 & 520,01 \\
$100 \%$ & Nangka & $35.795,88$ & 453,83 & 466,01 \\
\hline
\end{tabular}

\section{KESIMPULAN}

1. Perlakuan yang memberikan respon terbaik pada stabilisasi dimensi adalah pada kayu mangium dan konsentrasi parafin 33.3\%, sedangkan pada kayu nangka pada konsentrasi $66.6 \%$ (pengamatan pada saat kering udara).

2. Kadar air setelah perlakuan menunjukkan nilai yang lebih kecil dibandingkan dengan sebelum perlakuan (diduga parafin menggantikan posisi $\mathrm{OH}$ di dalam kayu).

3. Pemberian parafin tidak berpengaruh terhadap nilai MOE, MOR dan kekerasan kayu.

\section{DAFTAR PUSTAKA}

Coto Z. dan I.S. Rahayu. 2005. Pengaruh Perlakuan Vakum terhadap Absorbsi Air oleh Kayu dalam Proses Rendaman Dingin. Jurusan TEKNOLOGI Hasil Hutan, Institut Pertanian Bogor. Bogor.
Coto Z. 2005. Penurunan Kadar Air Keseimbangan dan Peningkatan Stabilitas Dimensi Kayu dengan Pemanasan dan Pengekangan. Jurnal IImu dan Teknologi Kayu Tropis, 3(1): 27-31.

Fengel, D. and G. Wegener. 1993. Kayu: Kimia, Ultrastruktur, Reaksi-Reaksi. Alih Bahasa: $\mathrm{H}$. Sostrohamidjojo. Gadjah Mada University Press. Yogyakarta.

Malik, J., S. Adi dan R. Osly. 2005. Sari Hasil Penelitian Mangium (Acacia mangium Wild). Http:///www.dephut.go.id. [03 April 2009].

Ramsden, M.J. and F.S.R.A. Blake. 1997. Kinetic Study of the Acetylation of Cellulose, Hemicellulose and Lignin Components in Wood. Wood. Sci. Technol., 31(1): 45-50.

Walker, J.C.F. 1993. Basic Wood Chemistry and Cell Wall Ultrastructure. Dalam Primary Wood Processing, Principles and Practice, Bab 2, Walker, J.C.F, editor, Chapmann \& Hall, London, 23-67.

Diterima :03 Desember 2007

\section{Syahidah}

Lab. Sifat Dasar dan Teknologi Kimia Hasil Hutan

Fakultas Kehutanan Universitas Hasanuddin

Jl. Perintis Kemerdekaan Km. 10 Tamalanrea, Makassar 90245

E-Mail: idha_unhas@yahoo.com

Tekat Dwi Cahyono

Staf Pengajar Program Studi Manajemen Hutan

Fakultas Pertanian Universitas Darussalam Ambon

Jl. Raya Tulehu, Km 24 Ambon - Maluku

Email: tekat@telkom.net 